\title{
DZIELNICA CZECHÓW W LUBLINIE - GENEZA UKŁADU URBANISTYCZNEGO
}

\author{
Natalia Przesmycka \\ Katedra Architektury, Urbanistyki I Planowania Przestrzennego, Wydział \\ Budownictwa i Architektury, Politechnika Lubelska \\ e-mail: n.przesmycka@pollub.pl
}

\begin{abstract}
Streszczenie. Geneza planowania i projektowania urbanistycznego układu Czechowa sięga okresu międzywojennego. Na dzisiejszy układ urbanistyczny składają się nie tylko opracowania dla poszczególnych osiedli powstające od początku lat 70. XX wieku, ale również przybliżony w artykule, wcześniejszy dorobek planistyczny i projektowy.
\end{abstract}

Słowa kluczowe: Lublin, Czechów, konkursy urbanistyczne, projektowanie urbanistyczne

\section{ZARYS HISTORII CZECHOWA}

Lubelska dzielnica Czechów jest jedną z największych dzielnic miasta. Obecnie podział administracyjny Lublina wyodrębnia Czechów Południowy (osiedla: Lipińskiego, Moniuszki, Wieniawskiego, Karłowicza, Nowowiejskiego i Lemszczyzna) oraz Czechów Północny (osiedla: Chopina, Paderewskiego, Szymanowskiego, Mackiewicza, Choiny i Bursaki).

Od strony południowej naturalną granicą jest dolina rzeki Czechówki. Od strony północnej graniczy obecnie z terenami wsi Jakubowie Konińskie i Kol. Dys - Południe.

W skład Czechowa wchodzą historyczne grunty dawnych własności ziemskich i folwarków: Bielszczyzny¹, Lemszczyzny, Czechówki Górnej (wsi), Czechowa Górnego oraz Czechowa Dolnego. Czechów zamienni bywał nazywany Czechówką. Tereny te były wykorzystywane rolniczo jako pola uprawne. Zabudowa skupiona była w dolinie Czechówki, w której oprócz łąk usytuowane były stawy hodowlane. Najbardziej okazałym budynkiem $\mathrm{w}$ tym rejonie, jest zachowany do dzisiaj budynek dworu rodziny Bielskich. Powstał on najprawdopodobniej w miejscu dawnego kościoła ariańskiego, zburzonego w czasie zamieszek religijnych po 1600 roku$^{2}$. Dwór wzniesiony na skarpie nad Czechówką wchodził w skład zabudowań folwarcznych i stanowił charakterystyczny punkt orientacyjny.

Drugim znaczącym budynkiem znajdującym się nad Czechówką po stronie przyszłej dzielnicy Czechów było fortalicjum sięgajace swoją historią końca XV wieku, ufundowane przez Piotra Konińskiego. Kolejnymi właścicielami były rodziny Lubomelskich i Tarłów. Posiadłością rodziny Tarłów była od XVIII wieku Czechówka Górna, w skład której wchodziły wówczas Wieniawa i Czechówka Dolna, staw i rzeka³. Pod koniec XVIII wieku, po katastrofie budowlanej zamek zaczął podupadać. Na początku XIX wieku był już tak zrujnowany, że na

1 Bielszczyzna stanowiła własność rodziny Bielskich od początku XVIII wieku; za: M. Buczyński, Nazwy dzielnic i przedmieść Lublina, [w:] Rocznik Lubelski, t. 5, 1962, s. 261. Folwark Bielszczyzna został przyłączony do Lublina w 1916 roku, a do 1880 należał do gruntów gminy Konopnica, za: Słownik Geograficzny, t. I, Warszawa 1880, s. 216.

2 Historia dworu Bielskich nie jest do końca wyjaśniona. Nosi on cechy budowli późnorenesansowej lub wczesnobarokowej. W XIX wieku folwark nabyli Chrzanowscy, którzy posiadali obiekt i resztówkę folwarku do lat 60-tych XX wieku.

3 Mazurkiewicz J., 1956, Jurydyki lubelskie, Wrocław, s. 102, 111. 
jego miejscu zbudowano parterowy dwór ${ }^{4}$. Lokalne legendy głosiły, że pomiędzy obydwoma siedzibami znajdowały się łączące je lochy5.

\section{CZECHÓW W OKRESIE MIĘDZYWOJENNYM}

W 1924 roku na miejscu dawnego zamku Tarłów wzniesiono kościół Mariawitów. Po przeciwnej stronie ówczesnej ul. Drobnej (dzisiejsza Aleja Kompozytorów Polskich) znajdowały się ciągle zabudowania folwarczne. W latach międzywojennych zabudowanie folwarczne znajdowały się również przy ulicy Bonifraterskiej (obecna Biernackiego). Na Czechowie znajdowały się dwie cegielnie.

W okresie międzywojennym władze miejskie zainteresowały się terenami leżącymi po północnej stronie Lublina, dostrzegając w nich potencjał dla lokalizacji przyszłej dzielnicy mieszkaniowej. W 1925 roku Towarzystwo Urbanistów Polskich ogłosiło ogólnopolski, otwarty Konkurs na szkic regulacyjny miasta Lublina ${ }^{6}$. Obszar przyszłego Czechowa oznaczono w załączniku graficznym jako ,grunta wsi przyłączonych” (Ryc. 1,2). W warunkach konkursu ich przeznaczenie określono jako terenów mieszkaniowych, oraz zabezpieczono obszar na budowę przyszłego szpitala centralnego. Wzdłuż rzeki Czechówki planowano wytyczenie dużej arterii komunikacyjnej, która miałaby odciążyć centrum. Warunki konkursu wskazywały również na konieczność rozwiązania problemu coraz bardziej zanieczyszczonej Czechówki, dopuszczając nawet możliwość jej przesklepienia i zamienienia w kolektor ścieków, bądź oczyszczenia, regulacji i osobnego rozwiązania kanalizacji ${ }^{7}$.

W 1926 roku do strefy interesów miasta Lublina, w związku z reformą rolną przyłączono oficjalnie: Lemszczyznę i Bielszczyznę, oraz Czechów i Czechówkę Górną (Gmina Konopnica). Jedynie Czechów należał wówczas do skarbu państwa, pozostałe były dobrami prywatnymi ${ }^{9}$.

Efektem konkursu były opracowania w formie koncepcji urbanistycznych, które miały stanowić wytyczne dla sporządzenia planu tzw. Wielkiego Lublina (Ryc. 3). We wszystkich trzech nagrodzonych pracach widoczne jest podobne podejście do zagospodarowania terenów mieszkaniowych Czechowa, jako dzielnicy o wyraźnie zaznaczonej strefie centralnej, połączonej komunikacją obwodową z pozostałą częścią miasta. Jednak poszczególni autorzy prac odmiennie potraktowali zagadnienie kompozycji urbanistycznej. W pracy nagrodzonej jako pierwsza E. Norwerth zaprojektował ułożenie głównej osi kompozycyjnej w kierunku północno - zachodnim, tworząc na jej przecięciu z arteriami obwodowymi dwa place: owalny i prostokątny. Od placu owalnego ulice miały rozchodzić się promieniście, wytyczając kwartały zabudowy. Autor drugiej nagrodzonej pracy, prof. I. Drexler na Czechowie zaprojektowal dość swobodny, ograniczy układ zabudowy jednorodzinnej skupionej wokół centralnych stref przestrzeni zielonych - lokalnych przestrzeni publicznych. Jest to bardzo wyraźne nawiązanie do idei Ebenezera Howarda - miast ogrodów (osiedle ogrodowe). Poprowadzone płynnymi liniami ulice i powiązane ze sobą „korytarzowo” strefy zieleni miejskiej bardzo dobrze wpisywałyby się w rozrzeźbioną topografię terenu. W trzeciej nagrodzonej pracy lubelskiego architekta J. Siennickiego dominuje prostokreślne powiązania osią komunikacyjną wschód

4 H. Gawarecki, Stanisław Krzesiński, Stanisław Krzesiński: „Dwa wrażenia... czyli Lublin jakim był w roku 1827 i jakim jest w roku 1877", Lublin 1877, s. 233.

5 Z. Sierpiński, Obraz miasta Lublina, Warszawa 1839, s. 57. Autor wspomina również, że „,przed kilkudziesięciu laty, lecz nie wiadomo w którem miejscu, pomiędzy Czechówką a Czwartkiem mały drewniany kościółek; starością zniszczał".

6 APL, AmL (1918-1939), sygn. 1788

7 Konkurs na szkic regulacyjny miasta Lublina, oprac. I. Kędzierski, Wyd. Magistrat Miasta Lublin, 1925.

8 Ustawa z dnia 28 grudnia 1925 o wykonaniu reformy rolnej (dz. U. R. P. nr 1, poz. 1 z 1926).

9 APL, PmL, sygn. 14. 
- zachód trzech lokalnych centrów przyszłych dzielnic. Od każdego z placów rozchodzą się ulice promieniście.

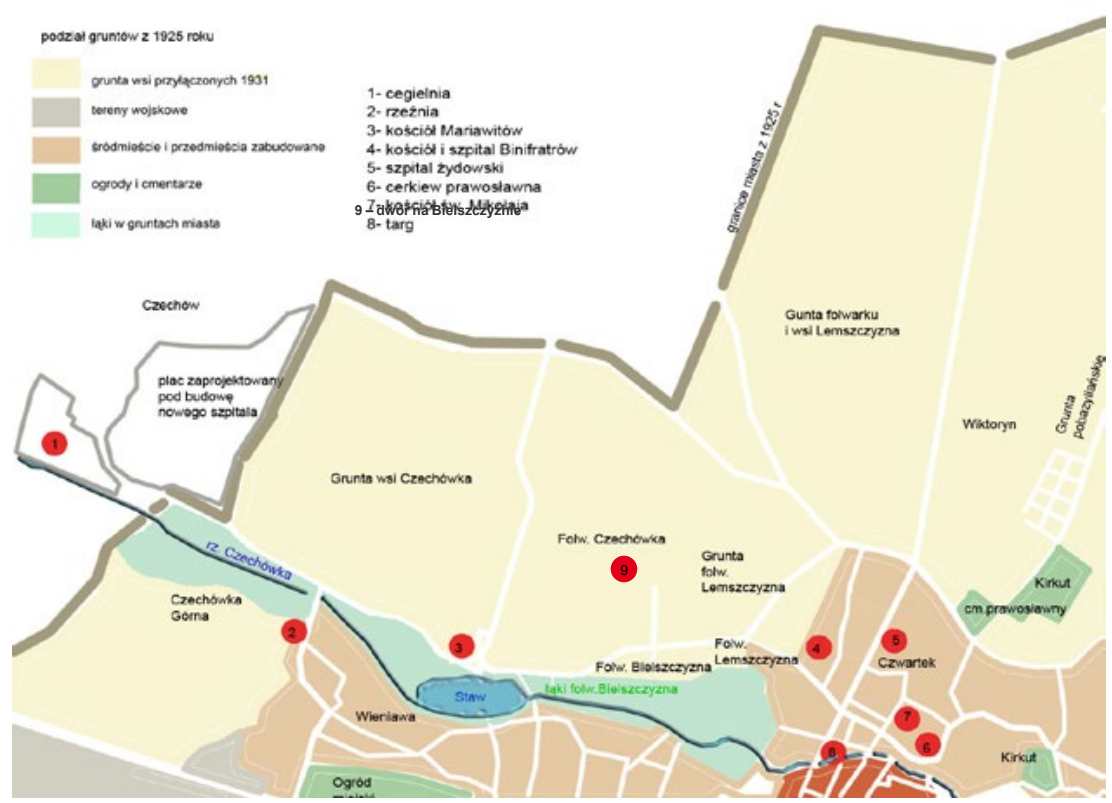

Ryc. 1. Schemat podziału gruntów Czechowa i okolic, wg stanu na rok 1925 i wytycznych do Konkursu na Plan Wielkiego Lublina. Rys. N. Przesmycka

Fig. 1. The scheme of the land division of Czechów and the surrounding areas, 1925, based on the guidelines attachment to the contest for the Great Lublin. Drawn by N. Przesmycka

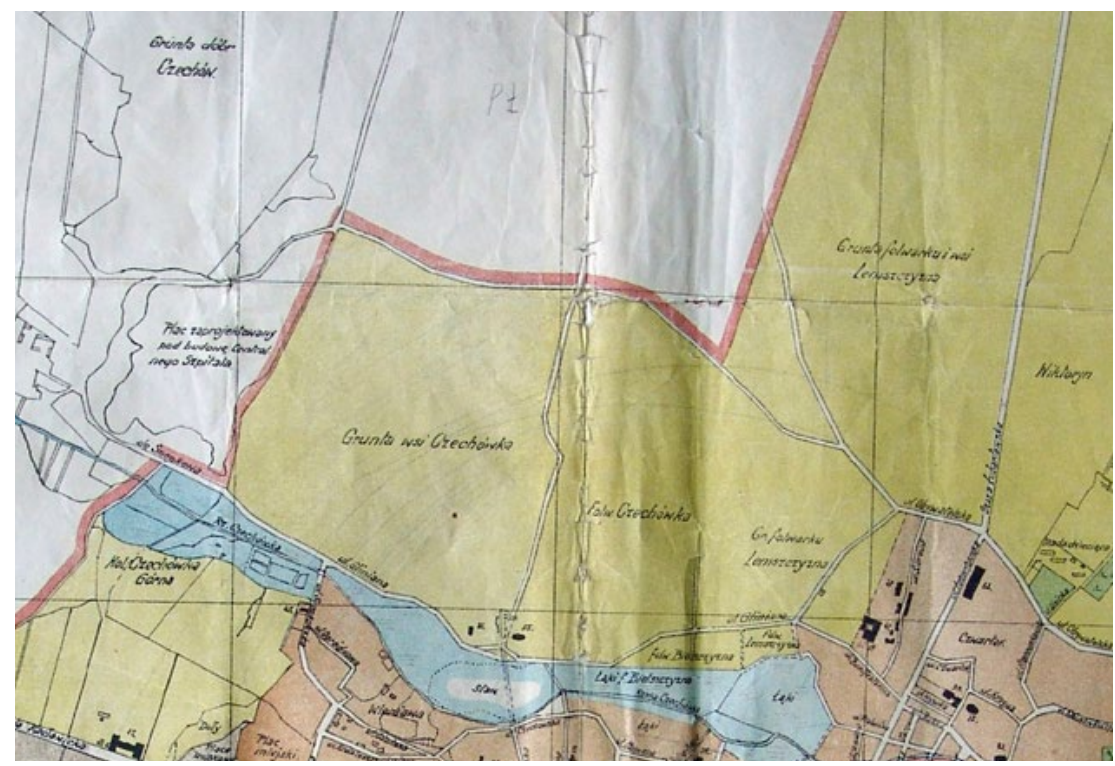

Ryc. 2. Załącznik graficzny do konkursu na Plan Wielkiego Miasta Lublina.

Źródło: Zb. Spec. Biblioteki UMCS, sygn. K 167/65/13

Fig. 2. The graphic attachment to The Contest on The great Lublin, source: Zb. Spec. Biblioteki UMCS, sygn. K 167/65/13 

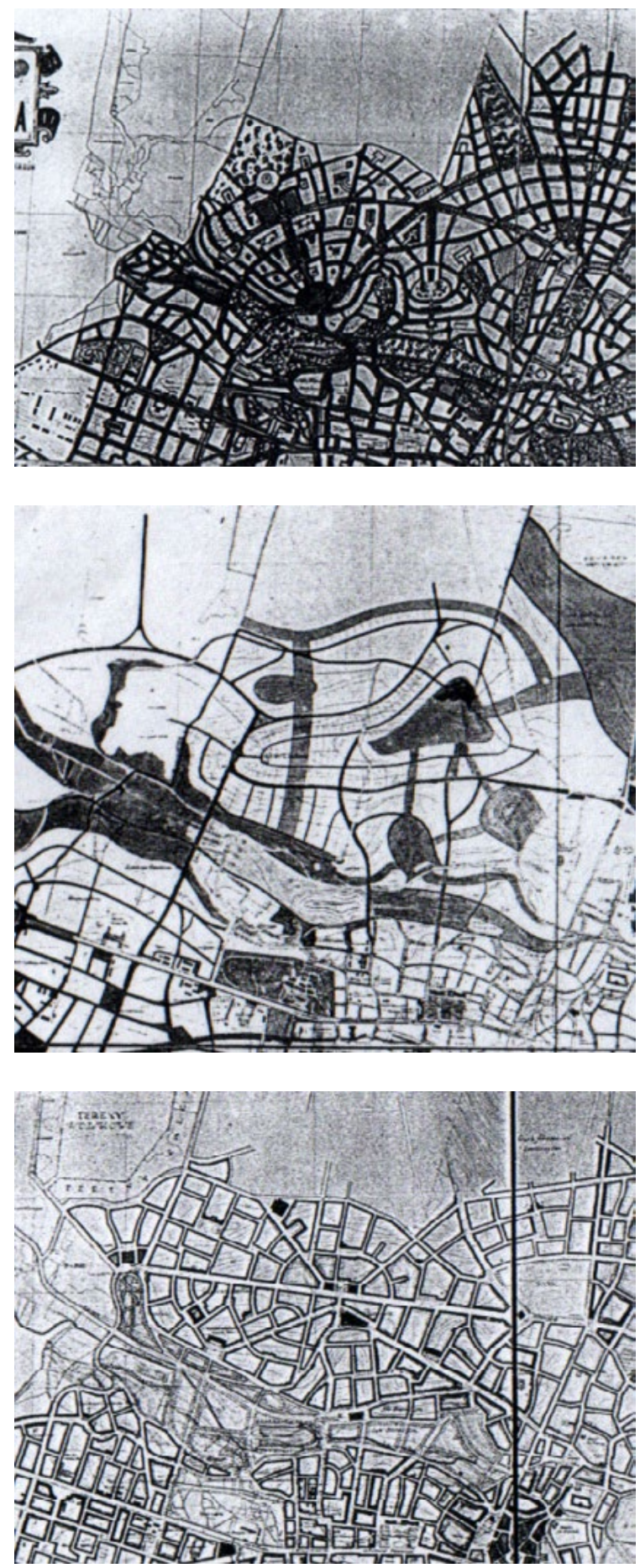

Ryc. 3. Prace Konkursowe. 1 - Nagroda I, inż. E. Norwerth, 2 - Nagroda II, prof. I. Drexler,

3 - Nagroda III, inż. J. Siennicki. źródło: APL, AmL (1918-1939), sygn. 1787

Fig. 3. The competition entries. $1^{\text {st }}$ Prize - E. Norwerth, $2^{\text {nd }}$ Prize - prof. I. Drexler, $3^{\text {rd }}$ Prize - J. Siennicki. Source: APL, AmL (1918-1939), sygn. 1787 
Nagrodzone prace potraktowane były jako źródło inspiracji i wytycznych dla sporządzanego przez Wydział Budownictwa Magistratu m. Lublina, a od 1938 roku przez Biuro Regulacji i Pomiarów, Planu Wielkiego Miasta Lublina (Ryc. 4. ${ }^{10}$.

W 1934 Wojewoda Lubelski w celu wsparcia drobnego budownictwa mieszkaniowego wydał zarządzenie zobowiązujące Zarząd Miasta do opracowania szczegółowego planu zagospodarowania gruntów państwowych na „Czechowie”.

Inwestycje budowlane na terenie Czechowa planowano rozłożyć na okres 2-3 lat. W maju 1935 roku Ministerstwo Spraw Wewnętrznych zatwierdziło opracowany przez Zarząd Miejski w Lublinie plan zabudowania Czechowa Dolnego i plan parcelacyjny wraz z wytyczeniem działek. Plan obejmował tereny bezpośrednio przyległe do granic administracyjnych miasta i leżące w strefie jego interesów.

Przyszłe tereny budowlane na Czechowie były pozbawione infrastruktury. Układ komunikacyjny stanowiły nieutwardzone polne drogi, których przebieg ukształtowany został w wyniku historycznych podziałów pól, własności i topografii. Uzbrojenie terenu w energię elektryczną inwestorzy mieli przeprowadzać we własnym zakresie, podobnie jak wykonanie studni i szamb.

Do II wojny światowej na terenie Czechowa powstały dwie kolonie domów mieszkalnych: Czechów Górny i Czechów Dolny. Na powierzchni około 3 ha zaplanowano budowę osiedla Towarzystwa Osiedli Robotniczych, jednak nie zostało ono zamieszkane przez robotników. Mieszkańcami byli głównie urzędnicy: pocztowi, wojskowi oraz emerytowani wojskowi niższych stopni. Wynikało to z cen nieruchomości: działki budowlane na Czechowie Górnym, (zajęte przez Legionową Spółdzielnię Mieszkaniową) kosztowały w 1937 roku ok. 50 gr za $1 \mathrm{~m}^{2}$, na Czechowie Dolnym ok. 40 gr., obszar 4,5 ha zarezerwowała Spółdzielnia Legionowa, 3,1 ha przypadło w udziale Spółdzielni Podoficerów, Legionistów i Pocztowców. W latach 1935-1936 przewidywano realizację 18 domów Spółdzielni Podoficerskiej, 10 domów dla Spółdzielni Legionowej i 35 dla Związku Legionistów ma Czechowie Dolnym. Architektura wznoszonych budynków nosiła cechy funkcjonalnego i ekonomicznego modernizmu. Zabudowa mieszkaniowa była jednorodzinna lub bliźniacza wznoszona z cegły, częściowo lub wcale nie podpiwniczona. Powstały się również budynki drewniane.

10 Plan, w formie szeregu planów rozwojowych opracowywany był w latach 1929-1931. Przez następne lata był modyfikowany, aktualizowany i poprawiany, zgodnie ze wskazówkami Ministerstwa Spraw Wewnętrznych. Kolejne opracowania tworzone były aż do wybuchu II wojny światowej. N. Przesmycka, Lublin. Przeobrażenia urbanistyczne 1815-1939, Politechnika Lubelska, Lublin 2012, s. 169-181 


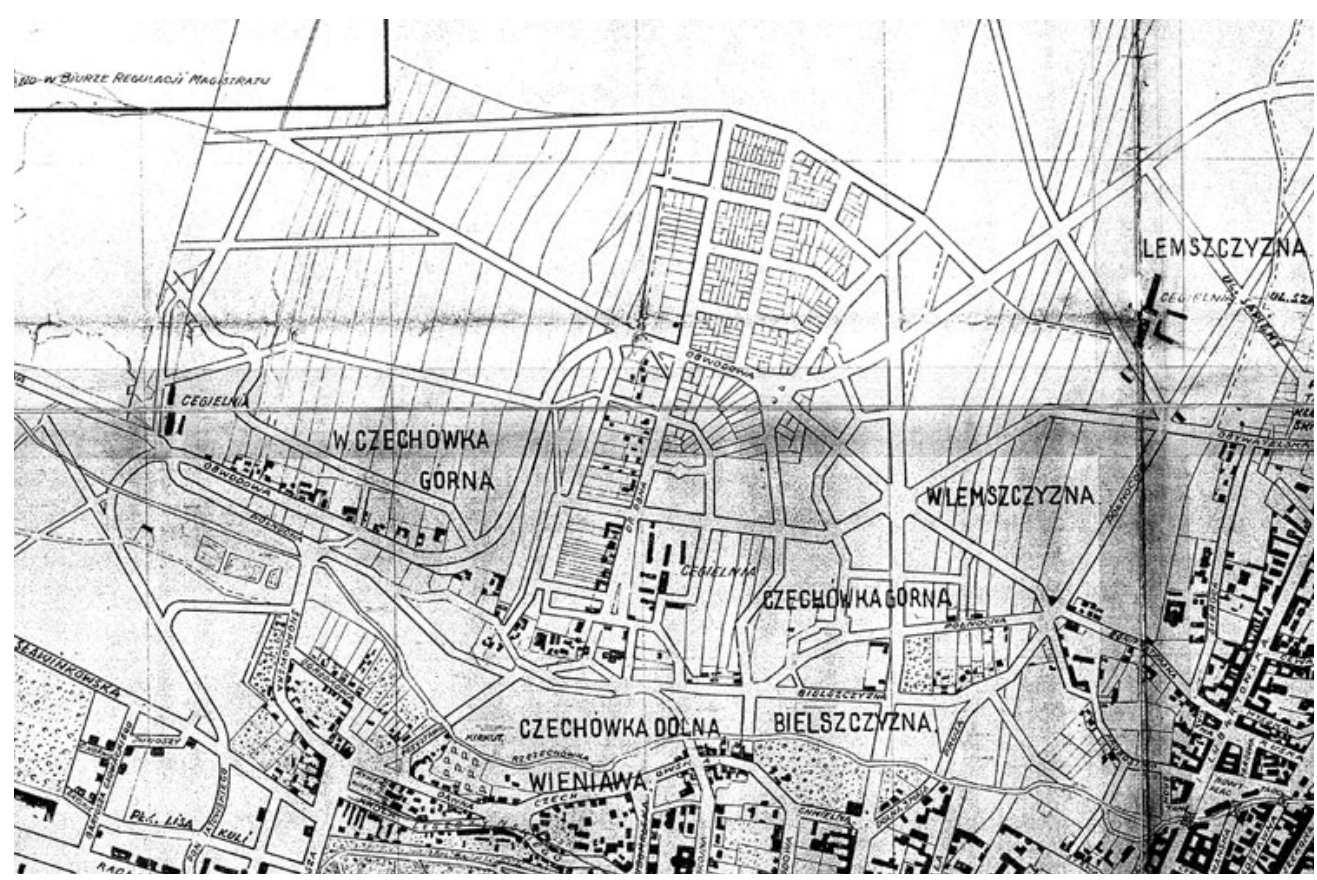

Ryc. 4. Fragment Planu Wielkiego Miasta Lublina 1934, z projektem parcelacji działek na terenie przyszłego Czechowa

Fig. 4. Fragment of the Plan of the Great City of Lublin 1934, with the project of plots parcelation on the area that is to be Czechów

Do roku 1937 zbudowano drogę dojazdową do nowej dzielnicy oraz wewnętrzne ulice. Władzom miasta zależało, aby na Czechowie zabudowa mieszkaniowa „była wykonana w sposób racjonalny, estetyczny i dostosowany do polityki mieszkaniowej miasta" ${ }^{11}$. W czerwcu 1937 roku Komisja Regulacyjna w Lublinie zaakceptowała plan zabudowy Czechowa Dolnego. Określono strefę zabudowy ogniotrwałej wzdłuż arterii komunikacyjnej łączącej miasto ze Sławinkiem oraz drewnianej od strony wsi Sławinek i łąk. Komisja zgodziła się również na budowę na tym terenie domów bliźniaczych ${ }^{12}$. W lipcu tegoż roku Wojewoda Lubelski wystąpił do Dyrekcji Izby Rolniczej w Lublinie o wyłączenie ze strefy rolnej części gruntów rolnych Czechowa i uznania ich za tereny budowlane. ${ }^{13}$

W latach 1937-1938 na Czechowie Górnym powstała kolonia mieszkaniowa Spółdzielni Legionistów, składająca się z kilkunastu budynków o spójnej architekturze. Budynki mieszkalne zaprojektowano jako powtarzalne bliźniaki (Ryc. 5.).

W domach znajdowały się trzy pokoje, łazienka, sień i magazynek. Kondygnacja parteru zbudowana była jako murowana, nad częścią budynku znajdowały się drewniane nadbudówki. Należy podkreślić, że było to jedyne w Lublinie osiedle z okresu międzywojennego, którego architekturę zaprojektowano jako spójną i powtarzalną. Do dnia dzisiejszego budynki nie zachowały swojego oryginalnego charakteru. Wznoszenie budynków mieszkalnych na terenie Czechowa Górnego i Dolnego trwało do 1939 roku.

11 APL, UWL WKB, sygn. 3336, s. 48.

12 Spółdzielnia Legionistów domagała się możliwości budowy domów wolno stojących oraz wystąpiła z prośbą o możliwość budowy domów drewnianych obłożonych cegłą ,,wobec tego, że 4 członkowie spółdzielni nabyli już drzewo na domy".

13 Przesmycka N., 2012, Lublin..., op. cit. 


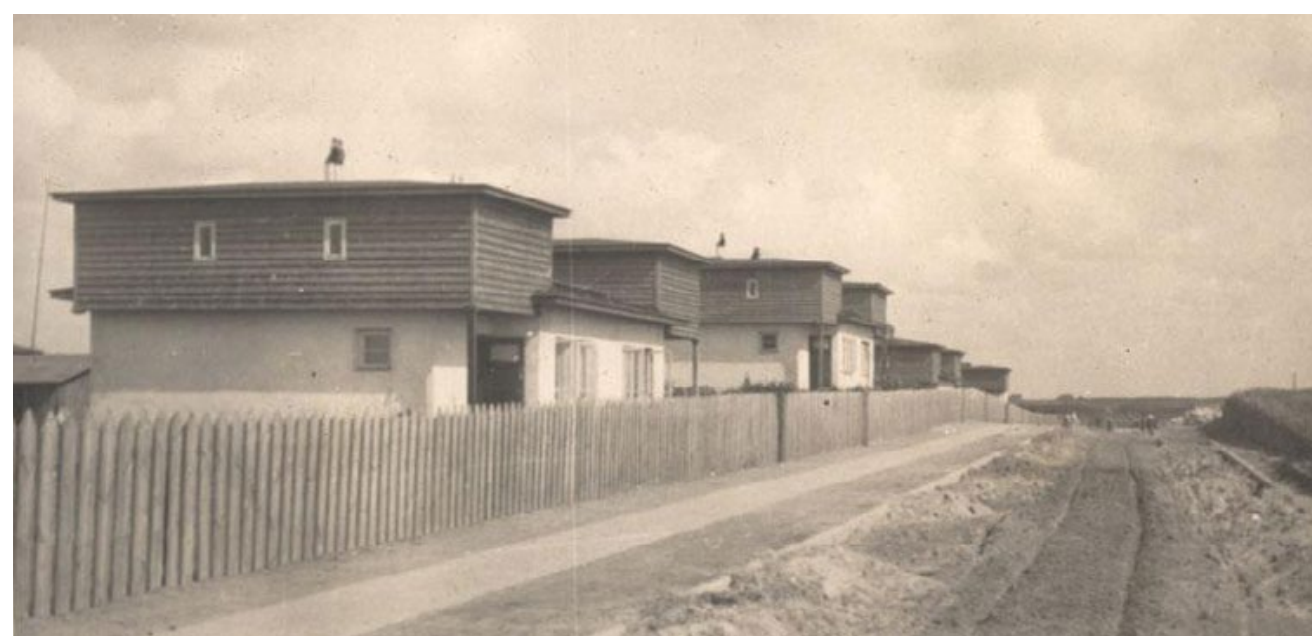

Ryc. 5. Kolonia Legionistów na Czechowie ul. Michała Wójtowicza, fotografia z lat 30-tych XX wieku, źródło: Zasób Ośrodka Brama Grodzka Teatr NN, Kolekcja Jolanty i Wojciecha Jurkiewiczów

Fig. 5. The Colony of the Legionnaires in Czechów, Michał Wójtowicz Str. Photo from 30ties. ot XX cent.

Source: Zasób Ośrodka Brama Grodzka Teatr NN, the collection of Jolanta and Wojciech Jurkiewicz

Duże zainteresowanie wzbudzał wśród potencjalnych spółdzielców również teren Lemszczyzny ${ }^{14}$, leżący w bliskim sąsiedztwie centrum miasta. Zgodnie z Planem Wielkiego Miasta Lublina przeznaczony był on pod zabudowę mieszkaniową. Dobra lokalizacja w sąsiedztwie centrum miasta dawała możliwość szybkiej zabudowy oraz łatwego doprowadzenia mediów: wody, kanalizacji i elektryczności (po dokończeniu budowy ulicy Prusa).

O nabycie obszaru o pow. ok. 18 ha, położonych przy obecnej ul Północnej, Bonifraterskiej i Obywatelskiej, wystąpił Bank Gospodarstwa Krajowego, działając jako przedstawiciel skarbu państwa. Tereny te stanowiły część gruntu folwarku Lemszczyzna należącego do rodziny Kleniewskich ${ }^{15}$. Skarb Państwa nabył obszar 19 ha w 1936 roku, w celu zorganizowania tam „Wzorowego osiedla mieszkaniowego".

Sprawę budowy osiedla mieszkaniowego poddał jednak w wątpliwość Prezydent Miasta Lublina, który proponował na tym terenie, budowę nowoczesnego szpitala klinicznego, spełniającego rolę lecznictwa dla nowo powstającego COP, oraz dla potrzeb Akademii Medycznej (w związku z projektem Departamentu Sanitarnego otworzenia w Lublinie Akademii Medycyny Sądowej) ${ }^{16}$. W lutym 1937 BGK w Warszawie powierzył inż. arch. Adamowi Paprockiemu opracowanie planu zabudowania terenu państwowego „Lemszczyzna”"17. W lutym 1938 roku, Prezydent wystąpił do Dyrekcji BGK z prośbą o odsprzedanie tych terenów Zarządowi Miasta, ale otrzymał negatywną odpowiedź zarówno z BGK jak i Ministerstwa Skarbu i Ministerstwa Spraw Wewnętrznych.

Do II wojny światowej wykonano jedynie częściową parcelację terenów na cele mieszkaniowe - budownictwa jednorodzinnego. Była one prowadzona w sposób racjonalny, uwzględniając topografię terenu. Wybuch wojny przerwał prace projektowe i do planowanych

149 kwietnia 1935 roku Związek Pracowników Poczty, Telegrafów i Telefonów w Lublinie przekazał do Urzędu Wojewódzkiego wykaz członków spółdzielni reflektujących na zakup działek budowlanych i budowę domów na terenie projektowanego zabudowania folwarku „Lemszczyzna”, APL, UWL WKB, sygn. 3337.

15 Komisja Komitetu Rozbudowy Lublina, wydała pozytywną opinie o celowości prowadzenia na tym terenie akcji budowlanej, APL, UWL WKB, sygn. 3337.

16 W piśmie z dnia 2 czerwca 1938 roku skierowanym do Ministra Spraw Wewnętrznych i Ministra Skarbu.

17 APL, UWL WKB sygn. 3337. 
inwestycji mieszkaniowych nie doszło. Pomysł prezydenta o lokalizacji w północnej części miasta szpitala przetrwał wojnę. Na terenach dawnej Lemszczyzny powstały budynki klinik medycznych Państwowego Szpitala Klinicznego nr 4.

Po 1944 roku w terenowym, lubelskim oddziale Centralnego Biura Projektów Architektonicznych i Budowlanych trwały prace nad kolejnymi opracowaniami urbanistycznymi.

W 1948 roku powstało opracowanie w skali 1:10.000, zatytułowane: Lublin-funkcjonalny podział terenu (Ryc. 6.). W dość szkicowy sposób ukazuje on ogólny projekt rozmieszczenia stref funkcjonalnych i układu komunikacji w mieście, stosunkowo widocznie kontynuując przedwojenną myśl urbanistyczną. Na terenie Czechowa zaprojektowano dwa prostokątne place, jako strefy centralne przyszłych części dzielnicy, odnosząc się do układu urbanistycznego wynikającego z przedwojennego rozparcelowania działek. Bezpośrednio do placów przylegają tereny przeznaczone pod budownictwo użyteczności publicznej. Wzdłuż Czechówki przebiega trasa komunikacyjna określona jako „droga pierwszej kategorii zewnętrznej”. Układ komunikacji w obrębie Czechowa nawiązuje do wytycznych z przedwojennego Planu Wielkiego Lublina.

W kolejnych latach podejście planistyczne uległo dużym zmianom. Prawdopodobnie wiązało się to z koniecznością dostosowywania powstających planów do wskazówek i uwag Kolegium Urbanistycznego, a wszystkie decyzje dotyczące urbanistyki zgodnie z zasadami centralizmu socjalistycznego powoływane były w stolicy. Socrealistyczny rozmach wkroczył do projektowania urbanistycznego, owocując nowymi planami miast i osiedli. W 1950 roku został opracowany przez znanego lubelskiego architekta Tadeusza Witkowskiego projekt urbanistyczny pt.: Lublin - ogólny plan zagospodarowania przestrzennego - wstępny. Dzielnica Pótnocna. Podział terenów i komunikacja, zieleń, ośrodki mieszkaniowe, oraz wstępny podziat strefowy (Ryc. 7. ${ }^{18}$. Nowe podejście widoczne jest w wielu aspektach: dzielnicę okala linia kolejowa, z dworcem usytuowanym na zakończeniu głównej osi kompozycyjnej układu, biegnącej w kierunku północ - południe, jako przedłużenie ulicy Trzeciego Maja. Oś tą wyznaczają dwa prostokątne place i równoległe ulice, otoczone budynkami użyteczności publicznej. Bezpośrednio z nimi sąsiaduje zabudowa kwartałowa określona $\mathrm{w}$ legendzie planu jako „mieszkalna wysoka - 4 kondygnacje”. Kwartały mają kształt prostokątów z wewnętrznymi zielonymi dziedzińcami. Zabudowa mieszkalna niska - 2 kondygnacyjna została uwzględniona jedynie tam, gdzie już istniała, oraz w zachodniej części terenu. Zaprojektowane przez Witkowskiego place miały mieć charakter reprezentacyjny, o czym świadczą zaznaczone schematycznie pomniki usytuowane na środku, podkreślające jeszcze bardziej osie symetrii. W tym projekcie można po raz pierwszy dopatrzeć się cech urbanistyki socrealistycznej przyszłej Dzielnicy Północnej - Czechowa.

18 Archiwum Miejskiej Pracowni Urbanistycznej UM Lublin. 


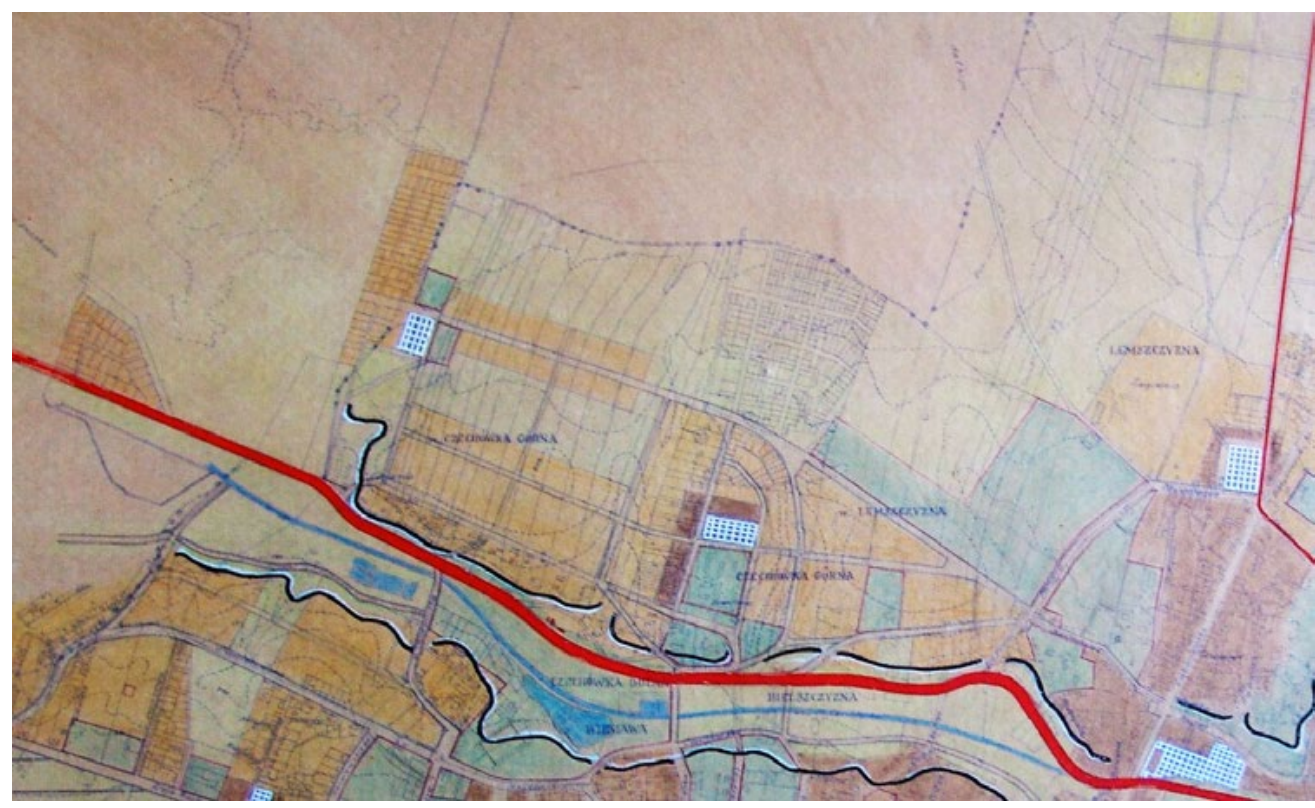

Ryc. 6. Lublin. Funkcjonalny Podział terenu - projekt. Fragment opracowania z 1948 roku. Własność UM Lublin.

Fig. 6. Lublin. The functional division of the area. Fragment opracowania z 1948 roku. Prioprety of UM Lublin.

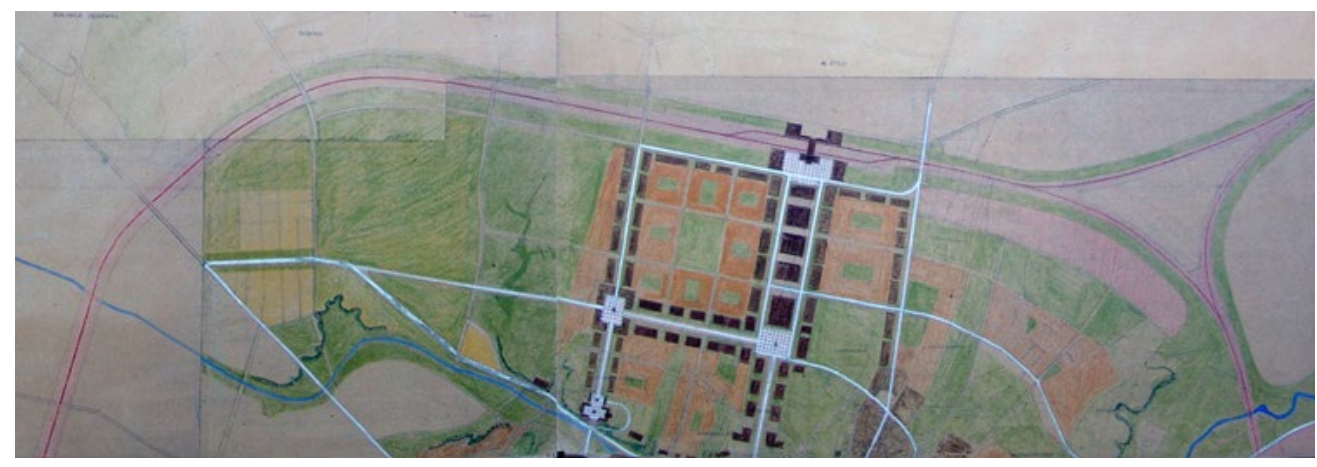

Ryc. 7. Lublin - ogólny plan zagospodarowania przestrzennego - wstępny. Dzielnica Pótnocna. Podział terenów i komunikacja, zieleń, ośrodki mieszkaniowe, oraz wstępny podziat strefowy, autorstwa T. Witkowskiego, 1950. Własność UM Lublin.

Fig. 7. Lublin - the preliminary master plan. The Northtern District. Land allocation, transportation, greenery, housing and general zoning. author T. Witkowski, 1950. Prioprety of UM Lublin.

W pierwszym ukończonym po II wojnie światowej ogólnym planie zagospodarowania przestrzennego Lublina opracowanym w 1954 roku można zauważyć dążenie do zgeometryzowania przyszłego układu urbanistycznego projektowanej dzielnicy, najprawdopodobniej wzorowany na planie z 1950 roku $^{19}$. W planie nie pojawia się jednak obwodowa linia kolejowa. Główna oś komunikacyjna dzielnicy, której towarzyszyć miała zieleń stanowić miała przedłużenie ulicy Trzeciego Maja w kierunku północnym. Wzdłuż niej zaplanowano realizację zwartej, wyższej zabudowy o charakterze śródmiejskim o funkcjach mieszkaniowych

19 Plan opracowano w nowo powołanej Miejskiej Pracowni Urbanistycznej. Ogólny plan zagospodarowania przestrzennego miasta Lublina, 1954, własność UM Lublin. 
i usługowych. Oś krzyżuje się z arterią komunikacyjną (obwodową) ${ }^{20}$, która w rejonie Czechowa poprowadzona została prostokreślnie, co podkreślało formalny charakter centralnej osi. Tereny zabudowy mieszkaniowej rozdzielone zostały dużymi obszarami zieleni rekreacyjnej, które łączyć miały centralną część dzielnicy z rekreacyjnymi terenami parkowymi zaplanowanymi wzdłuż Czechówki. W centrum dzielnicy zaplanowano tereny sportowe (stadion). W obrębie Czechowa zaprojektowano zróżnicowane rodzaje zabudowy.

Dwa lata później zmieniły się uwarunkowania społeczno-gospodarcze wyrosłe na fali krytyki niezrównoważonego rozwoju w okresie realizacji 6-letniego planu gospodarczego. W 1956 roku podjęto opracowywanie nowego planu zagospodarowania przestrzennego miasta Lublina, ,z docelową wizją w okresie kierunkowym, a w zakresie programu z wyodrębnieniem etapu 1965 roku oraz perspektywy 1980 ”21. Również ten plan wskazywał tereny Czechowa jako przyszłe dzielnice mieszkaniowe, jednak w ogólnym zarysie kształtowania się układu zabudowy i komunikacji różnił się przede wszystkim większą elastycznością (plan kierunkowy) oraz dostosowaniem do warunków naturalnych. Ustalenia planu stały się podstawą do udzielenia wytycznych urbanistycznych dla konkursu na projekt dzielnicy Czechów w 1965 roku.

W 1965 roku Oddział Lubelski SARP wystąpił do Prezydium MRN w Lublinie z propozycją zorganizowania konkursu zamkniętego na projekt zagospodarowania terenów dzielnicy Czechów ${ }^{22}$. Do udziału w konkursie zaproszono pracownie z Krakowa, Wybrzeża, Wrocławia, dwie z Katowic i trzy z Lublina. Zakres opracowania obejmować miał obszar około 330 ha, bez wyraźnie określonych granic. Wytyczne urbanistyczne wskazywały minimalne i maksymalne granice opracowania, obowiązujące powiązania komunikacyjne, ciągi zieleni oraz ogólne wskazanie postulowanego przebiegu tras komunikacyjnych. Zaplanowano budowę mieszkań dla 40.000 mieszkańców (+-10\%). W wytycznych konkursu nie określono struktury mieszkań ani procentu zabudowy wysokiej. Zabudowa miała przebiegać etapami.

Konkurs przyniósł rezultaty w formie koncepcji zagospodarowania terenu uwzględniających szczególną topografię dzielnicy. Nie przyznano pierwszej nagrody, a za najlepiej spełniającą założenia konkursu uznano pracę $\mathrm{nr} 2$ (Ryc. 8.), która zdobyła pierwsze wyróżnienie (zespół autorski z Krakowa, architekci: Leszek Filar, Zuzanna Perchal-Filar, Czesław Gawor, Jerzy Pilitowski, komunikacja inż. Henryk Ciońćka, uzbrojenie terenu: inżynierowie Jan Wydro i Stanisław Kudziełka). Pracę opisano jako trafnie rozwijającą decyzje planu ogólnego. Podkreślano „czytelny układ tras komunikacyjnych i ciągów pieszych, bardzo dobrą lokalizację i ekspozycję ośrodka usługowego. Prawidłowy i zharmonizowany z warunkami naturalnymi podział na jednostki przestrzenne o wyraźnym indywidualnym charakterze. Układ zabudowy podkreśla zarówno walory krajobrazu, jak i strukturę dzielnicy". ${ }^{23}$

20 Ulica obwodowa ta przebiegać miała od skrzyżowania z arterią wzdłuż Czechówki, jako przedłużenie ulicy Długosza, przez Czchów do przedłużenia ulicy Lubartowskiej, zamykając trym samym obszar zabudowany po północnej stronie miasta.

21 Furgał E., Ogólny plan zagospodarowania przestrzennego m. Lublina z 1959 roku, [w:] Lubelska Pracownia Urbanistyczna 1955-2005, Lublin 2005.

22 K. Majewski, Dzielnica mieszkaniowa Czechów w Lublinie. Konkurs zamknięty SARP nr 424, Architektura, 10 (287)/1971, s. 378

23 Ibid. s. 380 

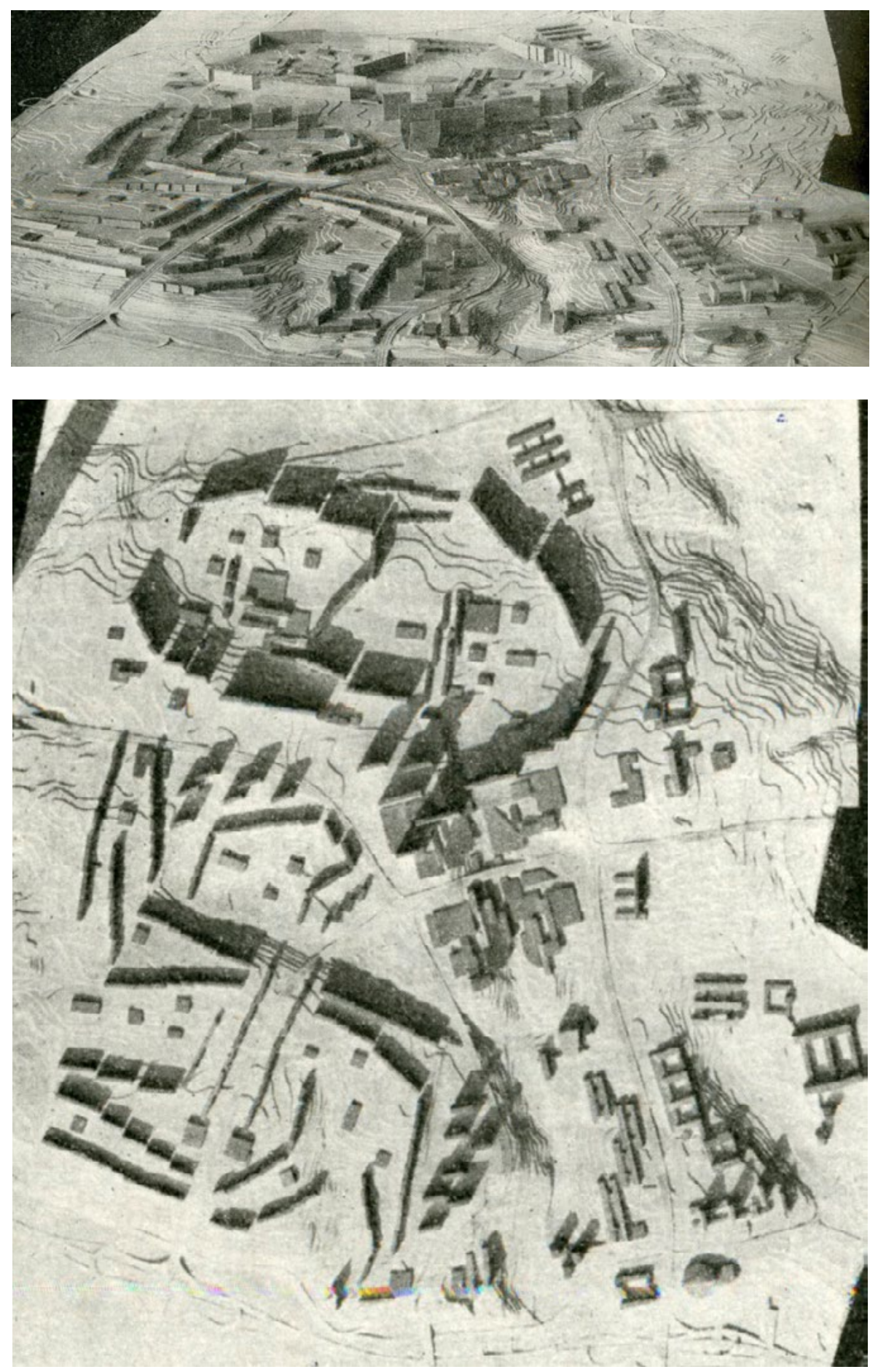

Ryc. 8. Wyróżnienie I - model konkursowy. Rep. Za: Architektura, 10 (287)/1971, s. 380

Fig. 8. The First Special mention - a contest model Rep. from: Architectura, 10 (287)/1971, p. 380 


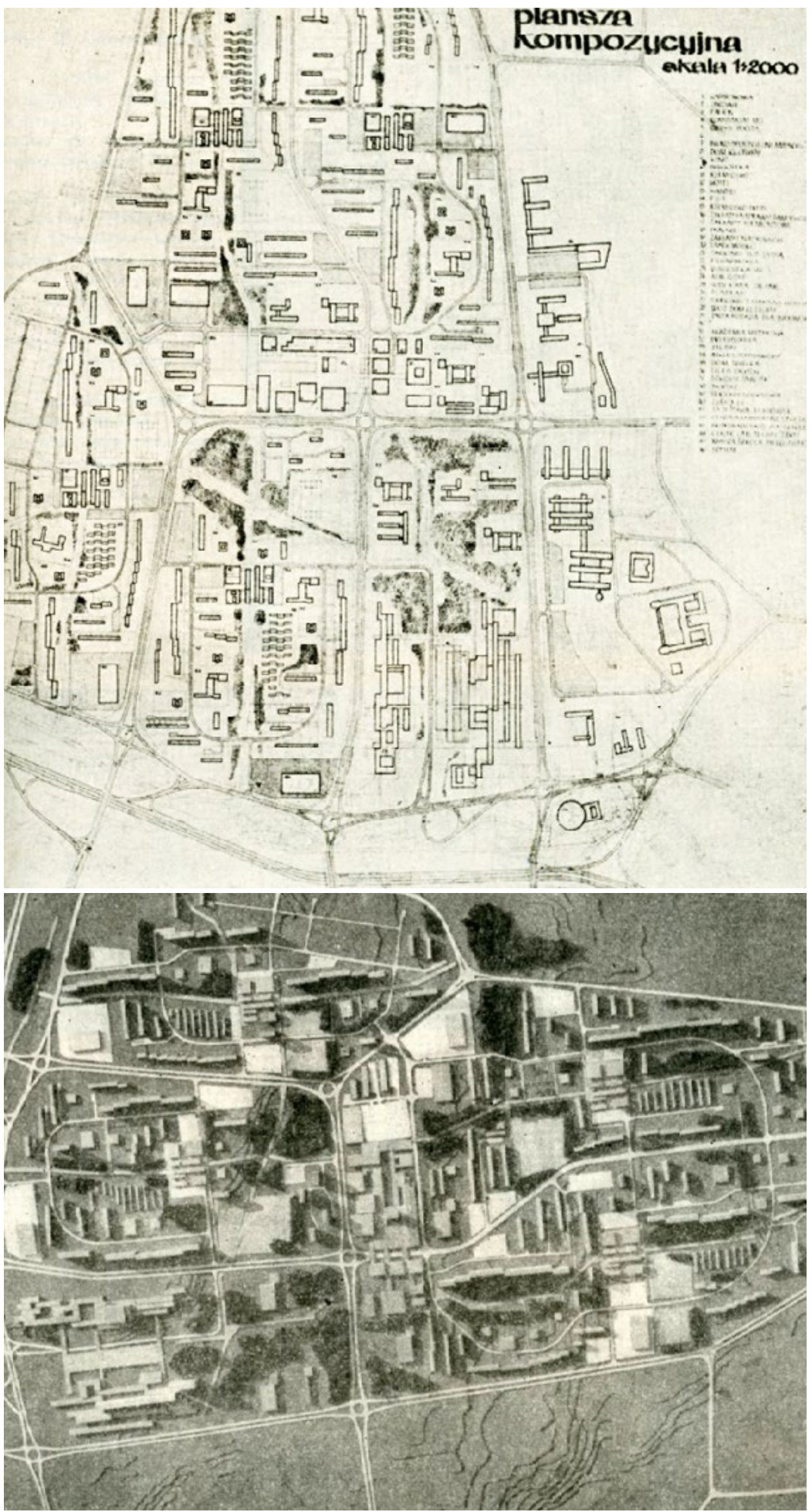

Ryc. 9. Plansza kompozycyjna oraz model, nagroda II, Rep. Za: Architektura, 10 (287)/1971, s. 379

Fig. 9. Urban composition board and the model, The Second Prize, Rep. Za: Architektura, 10 (287)/1971, p. 379 
Do pierwszego etapu realizacji budynków mieszkaniowych przewidziano system OWT. Był to najpopularniejszy w kraju system w latach 70-tych. Oprócz niego na Czchowie zrealizowano budynki wielkiego bloku WBLŻ z regionalnym dla Lubelszczyzny rozwiązaniem ścian osłonowych ze Scalonych Elementów Gazobetonowych ${ }^{24}$.

Wyniki konkursu zostały uwzględnione w ogólnym planie zagospodarowania przestrzennego Lublina z 1969 roku. Na Czechowie zaprojektowana została wyłącznie zabudowa mieszkaniowa wielorodzinna $\mathrm{z}$ towarzyszącym zapleczem usługowym (o charakterze lokalnym, dzielnicowym) i zielonymi terenami rekreacyjnymi. W południowo-wschodniej części Czechowa wyznaczono obszar dla jednej z czterech państwowych uczelni - Akademii Medycznej. Miejscowy Plan Szczegółowy Czechowa został uchwalony w dniu 13 grudnia 1972 roku zarządzeniem Prezydenta Miasta Lublin pod numerem/U/119/316/72/72. ${ }^{25}$

„Spółdzielnia Mieszkaniowa Czechów w Lublinie” została powołana 12 listopada 1974 roku. Prezesem został Stanisław Żaczek (prezes Spółdzielni Mieszkaniowej „Motor”). Obszar dzielnicy został podzielony na siedem osiedli. W latach 1975-80 przewidywano zbudowanie 13-tu tysięcy mieszkań w tzw. starych i nowych normatywach powierzchni użytkowej oraz w kategoriach od M-1 do M-7. Przewidywana powierzchnia usługowa miała wynosić około 186 tys. $\mathrm{m}^{2} .^{26}$

Jako pierwsze powstało osiedle „B”, , roboczo zwane „Łany” (dzisiejsze osiedle im. Stanisława Moniuszki). W marcu 1975 roku Lubelskie Przedsiębiorstwo Budowlane rozpoczęło prace budowlane. W blokach mieszkalnych o wysokości od 5 do 11 kondygnacji, mieściło się 1593 mieszkań, co miało stanowić bazę dla ok. 6500 osób, czyli zapewnić realizację połowy zamierzonego planu. Rok później dokonano rozdziału mieszkań: „W oparciu o nową politykę mieszkaniową państwa, którą określało hasło „mieszkanie dla dobrych pracowników uspołecznionych zakładów pracy". Mieszkania rozdzielano na poziomie wojewódzkim, wraz z Zarządem WSM. W 1975 roku na mieszkanie w Spółdzielni „Czechów” oczekiwało 1278 robotników, 1853 pracowników umysłowych, 137 emerytów i rencistów, 165 przedstawicieli studiującej i uczącej się młodzieży oraz 294 członków określanych mianem pozostali. Przydział mieszkań w pierwszym roku przewidywał ich rozdział według następującego klucza: 130 mieszkań przeznaczono na wykwaterowania inwestycyjne i kadrowe Urzędu Miejskiego, 84 - oddano jako budownictwo zakładowe, 150 mieszkań przekazano do sprzedaży (za dolary) Biuru Handlu Zagranicznego „Locum”, a 62 mieszkania planowano rozdzielić między członków Spółdzielni. Pozostałe stanowiły rezerwę. ${ }^{27} \mathrm{~W}$ październiku 1975 roku Lubelskie Przedsiębiorstwo Budownictwa Mieszkaniowego rozpoczęło budowę kolejnego osiedla Czechowa Osiedla im. Henryka Wieniawskiego.

Po czterech latach Spółdzielnia Mieszkaniowa „Czechów” składała się z pięciu osiedli: Moniuszki, Wieniawskiego, Lipińskiego, Chopina i Szymanowskiego, licząc około 24 tyś. Mieszkańców. Autorami projektów architektonicznych osiedli Moniuszki, Wieniawskiego i Lipińskiego byli Rita i Tadeusz Nowakowscy ${ }^{28}$. Osiedle Chopina powstało według projektu Bogdana Jezierskiego. Osiedle Szymanowskiego i Paderewskiego zaprojektował arch. Andrzej Lis. Osiedle Karłowicza - ostatnie osiedle wchodzące w skład dzielnicy Czechów, zaprojektował arch. Stanisław Machnik.

24 Ostańska A., Problemy rewitalizacji prefabrykowanej zabudowy mieszkaniowej na przykładzie osiedla im. St. Moniuszki w Lublinie, Budownictwo i Architektura, nr 4 (2009), s. 85-104.

25 Katalog Opracowań Planistycznych, w: Lubelska Pracownia Urbanistyczna 1955-2005, Lublin 2005, s. 135.

26 http://www.sm-czechow.lublin.pl/index.php/o-spoldzielni/historia

27 Ibid.

28 Przy projektowaniu osiedla Moniuszki współpraca Janusz Gągała. 


\section{PIŚMIENNICTWO}

Buczyński M., 1962. Nazwy dzielnic i przedmieść Lublina, Rocznik Lubelski, t.5, 1962.

Furgał E., 2005, Ogólny plan zagospodarowania przestrzennego m. Lublina z 1959 roku, [w:] Lubelska Pracownia Urbanistyczna 1955-2005, Lublin.

Gawarecki H., 1958. Stanisław Krzesiński, Stanisław Krzesiński: „Dwa wrażenia... czyli Lublin jakim był w roku 1827 i jakim jest w roku 1877", Rocznik Lubelski t. 1.

Lubelska Pracownia Urbanistyczna 1955-2005, Lublin 2005.

Majewski K., 1971. Dzielnica mieszkaniowa Czechów w Lublinie. Konkurs zamknięty SARP nr 424, Architektura, 10 (287)/1971.

Mazurkiewicz J., 1956, Jurydyki lubelskie, Wrocław.

Ostańska A., 2009. Problemy rewitalizacji prefabrykowanej zabudowy mieszkaniowej na przykładzie osiedla im. St. Moniuszki w Lublinie, Budownictwo i Architektura, nr 4 (2009).

Przesmycka N., 2012. Lublin. Przeobrażenia urbanistyczne 1815-1939, Politechnika Lubelska, Lublin.

Sierpiński Z., 1839, Obraz miasta Lublina, Warszawa.

\section{ŹRÓDŁA}

Archiwum Państwowe Lublin, Akta miasta Lublina (1918-1939), sygn. 1787, 1788.

Archiwum Państwowe Lublin, Plany miasta Lublina, sygn. 14.

Archiwum Państwowe Lublin, Urząd Wojewódzki Lubelski, Wojewódzka Komisja Budowlana, sygn.: 3337, 2901, 3154.

Konkurs na szkic regulacyjny miasta Lublina, oprac. I. Kędzierski, Wyd. Magistrat Miasta Lublin, 1925.

Lublin - funkcjonalny podział terenu, 1948, własność UM Lublin.

Ogólny plan zagospodarowania przestrzennego miasta Lublina, 1954, własność UM Lublin.

Plan Wielkiego Miasta Lublina, 1931, 1934, zbiory własne.

Ustawa z dnia 28 grudnia 1925 o wykonaniu reformy rolnej (dz. U. R. P. nr 1, poz. 1 z 1926).

Witkowski T., Lublin - ogólny plan zagospodarowania przestrzennego-wstępny. Dzielnica Pótnocna. Podziat terenów i komunikacja, zieleń, ośrodki mieszkaniowe, oraz wstępny podział strefowy, 1950, własność UM Lublin.

Załącznik graficzny do konkursu na Plan Wielkiego Miasta Lublina. Źródło: Zb. Spec. Biblioteki UMCS, sygn. K $167 / 65 / 13$

Zasób Ośrodka Brama Grodzka Teatr NN, Kolekcja Jolanty i Wojciecha Jurkiewiczów

\section{THE CZECHÓW DISTRICT IN LUBLIN - THE GENESIS OF URBAN PLAN}

\section{Summary.}

The genesis of planning and urban design of the Czechów district in Lublin dates back to the interwar period. The present urban layout consists of not only the development of individual estates formed from the early 70s, but also of planning and design from earlier period which are described in the paper.

Key words: Lublin, Czechów, urban design contests, urban planning 